\title{
Reductive nitrosylation of ferric cyanide horse heart myoglobin is limited by cyanide dissociation
}

\author{
Paolo Ascenzi ${ }^{\mathrm{a}, *}$, Alessandra di Masi ${ }^{\mathrm{a}}$, Francesca Gullotta ${ }^{\mathrm{a}}$, Marco Mattu $^{\mathrm{a}}$, Chiara Ciaccio ${ }^{\mathrm{b}, \mathrm{c}}$, \\ Massimo Coletta ${ }^{\text {b,c }}$ \\ a Department of Biology and Interdepartmental Laboratory for Electron Microscopy, University 'Roma Tre', Viale Guglielmo Marconi 446, I-00146 Roma, Italy \\ ${ }^{\mathrm{b}}$ Department of Experimental Medicine and Biochemical Sciences, University of Roma 'Tor Vergata', Via Montpellier 1, I-00133 Roma, Italy \\ ${ }^{\mathrm{c}}$ Interuniversity Consortium for the Research on the Chemistry of Metals in Biological Systems (CIRCMSB), Piazza Umberto I 1, I-87100 Bari, Italy
}

\section{A R T I C L E I N F O}

\section{Article history:}

Received 13 January 2010

Available online 29 January 2010

This paper is dedicated to Beatrice A.

Wittemberg who pioneered cyanide binding to globins.

\section{Keywords:}

Ferric cyanide horse heart myoglobin

Nitrogen monoxide

Reductive nitrosylation

Kinetics

\begin{abstract}
A B S T R A C T
Cyanide binds to ferric heme-proteins with a very high affinity, reflecting the very low dissociation rate constant $\left(k_{\text {off }}\right)$. Since no techniques are available to estimate $k_{\text {off }}$, we report herewith a method to determine $k_{\text {off }}$ based on the irreversible reductive nitrosylation reaction to trap ferric myoglobin ( $\mathrm{Mb}(\mathrm{III})$ ). The $k_{\text {off }}$ value for cyanide dissociation from ferric cyanide horse heart myoglobin ( $\mathrm{Mb}$ (III)-cyanide) was determined at $\mathrm{pH} 9.2$ and $20.0^{\circ} \mathrm{C}$. Mixing $\mathrm{Mb}$ (III)-cyanide and $\mathrm{NO}$ solutions brings about absorption spectral changes reflecting the disappearance of $\mathrm{Mb}$ (III)-cyanide with the concomitant formation of ferrous nitrosylated $\mathrm{Mb}$. Since kinetics of reductive nitrosylation of $\mathrm{Mb}(\mathrm{III})$ is much faster than $\mathrm{Mb}(\mathrm{III})$-cyanide dissociation, the $k_{\text {off }}$ value, representing the rate-limiting step, can be directly determined. The $k_{\text {off }}$ value obtained experimentally matches very well to that calculated from values of the second-order rate constant $\left(k_{\text {on }}\right)$ and of the dissociation equilibrium constant $(K)$ for cyanide binding to $\mathrm{Mb}(\mathrm{III})\left(k_{\text {off }}=k_{\text {on }} \times K\right)$.

(c) 2010 Elsevier Inc. All rights reserved.
\end{abstract}

Cyanide is one of the few ligands able to interact with both ferric and ferrous heme-proteins, albeit with very different thermodynamic and kinetic parameters. Cyanide binds to ferric hemeproteins with a very high affinity; values of the dissociation equilibrium constant (i.e., $K$ ) have been estimated to be lower than $10^{-5} \mathrm{M}$. This reflects primarily the very low first-order rate constant of cyanide dissociation (i.e., $k_{\text {off }}$ ) ranging between $10^{-2} \mathrm{~s}^{-1}$ and $10^{-7} \mathrm{~s}^{-1}$. In fact, values of the second-order rate constant for cyanide binding to ferric heme-proteins (i.e., $k_{\text {on }}$ ) range between $10^{2} \mathrm{M}^{-1} \mathrm{~s}^{-1}$ and $10^{4} \mathrm{M}^{-1} \mathrm{~s}^{-1}$. In contrast, the affinity of cyanide for ferrous heme-proteins is low, values of the dissociation equilibrium constant (i.e., $D$ ) being usually higher than $10^{-2} \mathrm{M}$. In fact, values of the first-order rate constant for cyanide dissociation from ferrous heme-proteins (i.e., $d_{\text {off }}$ ) range between $10^{-2} \mathrm{~s}^{-1}$ and $1 \mathrm{~s}^{-1}$, and values of the second-order rate constant for cyanide binding to ferrous heme-proteins (i.e., $d_{\text {on }}$ ) vary between $5 \times 10^{-1} \mathrm{M}^{-1} \mathrm{~s}^{-1}$ and $5 \mathrm{M}^{-1} \mathrm{~s}^{-1}$. Only ferrous Campylobacter jejuni truncated-hemoglobin P displays a very high reactivity for cyanide, reflecting an

Abbreviations: heme-Fe(III), ferric heme-protein; heme-Fe(III)-cyanide, ferric cyanide heme-protein; heme-Fe(II), ferrous heme-protein; Mb, myoglobin; Mb(III), ferric $\mathrm{Mb}$; $\mathrm{Mb}$ (III)-cyanide, ferric cyanide $\mathrm{Mb}$; $\mathrm{Mb}$ (III)-NO, ferric nitrosylated $\mathrm{Mb}$; $\mathrm{Mb}(\mathrm{II})$, ferrous $\mathrm{Mb}$; $\mathrm{Mb}(\mathrm{II})-\mathrm{NO}$, ferrous nitrosylated $\mathrm{Mb}$.

* Corresponding author. Fax: +39065733 6321.

E-mail address: ascenzi@uniroma3.it (P. Ascenzi). unusual stabilization mode of the heme-bound cyanide. Indeed, the X-ray crystal structure of the cyanide derivative shows that the ligand is hydrogen bonded to the phenolic OH group of TyrB10 and to the indole nitrogen atom of TrpG8 $[1,2]$.

Although the reaction of cyanide with ferric heme-proteins has received large attention, only values of $k_{\text {on }}$ are usually determined due to the very high ligand affinity and the very slow dissociation kinetics $[1,2]$. It is important to outline that a puzzling unexplained feature of the equilibrium curves of ferric horse heart myoglobin $(\mathrm{Mb}(\mathrm{III}))$ with cyanide is the value of the Hill coefficient $n$, which is considerably higher than 1 , that is a paradoxical result for a monomeric heme-protein. However, this feature might be related to either $(i)$ the very slow approach to equilibrium at low cyanide concentration, and/or (ii) the uncertainty on the determination of free cyanide at low cyanide concentration [3]. Furthermore, no methods are available to determine directly $k_{\text {off, }}$ which is estimated generally from values of $k_{\text {on }}$ and $K$ (i.e., $k_{\text {off }}=k_{\text {on }} \times K$ ).

The present study reports a method, based on the irreversible reductive nitrosylation reaction to trap cyanide-free $\mathrm{Mb}(\mathrm{III})$, which allows to determine directly the $k_{\text {off }}$ value for cyanide dissociation from ferric cyanide horse heart myoglobin (Mb(III)-cyanide). Mixing of $\mathrm{Mb}(\mathrm{III})$-cyanide and $\mathrm{NO}$ solutions induces the disappearance of $\mathrm{Mb}(\mathrm{III})$-cyanide with the concomitant formation of ferrous nitrosylated $\mathrm{Mb}(\mathrm{Mb}(\mathrm{II})-\mathrm{NO})$. Since $\mathrm{Mb}(\mathrm{III})$-cyanide dissociation represents the rate-limiting step of the whole process, the $k_{\text {off }}$ value 
can be easily determined. Moreover, both $K$ and $k_{\text {on }}$ values for cyanide binding to $\mathrm{Mb}(\mathrm{III})$ have been determined. As expected for a simple system [3], the $k_{\text {off }}$ value obtained experimentally matches very well to that calculated from values of $k_{\text {on }}$ and $K$ (i.e., $\left.k_{\text {off }}=k_{\text {on }} \times K\right)$ and the equilibrium curve is characterized by a Hill coefficient $n=1.01 \pm 0.02$.

\section{Materials and methods}

Horse heart $\mathrm{Mb}(\mathrm{III})$ was obtained from Sigma-Aldrich (St. Louis, MO, USA). The $\mathrm{Mb}(\mathrm{III})$ solution $\left(5.6 \times 10^{-5} \mathrm{M}\right)$ was prepared by dissolving $\mathrm{Mb}(\mathrm{III})$ in $2 \%$ borate buffer, $\mathrm{pH} 9.2$, at $20.0^{\circ} \mathrm{C}$. The $\mathrm{Mb}(\mathrm{III})$ concentration was determined spectrophometrically with values of $\lambda_{\max }$ and $\varepsilon$ given in Table 1S [3].

NO (from Aldrich Chemical Co., Milwaukee, WI, USA) was purified by flowing through an $\mathrm{NaOH}$ column in order to remove acidic nitrogen oxides. The NO stock solution was prepared by keeping in a closed vessel the $2.0 \%$ borate buffer solution ( $\mathrm{pH} 9.2$ ) under NO at $P=760.0 \mathrm{~mm} \mathrm{Hg}$ anaerobically $\left(T=20.0^{\circ} \mathrm{C}\right)$. The solubility of NO in the aqueous buffered solution is $2.05 \times 10^{-3} \mathrm{M}$, at $P=760.0 \mathrm{~mm}$ $\mathrm{Hg}$ and $T=20.0^{\circ} \mathrm{C}$ [3]. All the other products (from Merck AG, Darmstadt, Germany; and Sigma-Aldrich, St. Louis, MO, USA) were of analytical grade and used without purification unless stated.

The horse heart $\mathrm{Mb}(\mathrm{III})$-cyanide solution $\left(5.6 \times 10^{-6} \mathrm{M}\right.$ and $5.6 \times 10^{-5} \mathrm{M}$ ) was obtained by adding a 10 -molar excess of the cyanide stock solution $\left(1.0 \times 10^{-2} \mathrm{M}\right)$ to the $\mathrm{Mb}(\mathrm{III})$ solution $\left(5.6 \times 10^{-6} \mathrm{M}\right.$ and $\left.5.6 \times 10^{-5} \mathrm{M}\right)[3]$.

The horse heart $\mathrm{Mb}(\mathrm{II})-\mathrm{NO}$ solution $\left(5.6 \times 10^{-6} \mathrm{M}\right.$ and $\left.5.2 \times 10^{-5} \mathrm{M}\right)$ was obtained by adding a 10 -molar excess of the NO stock solution $\left(2.05 \times 10^{-3} \mathrm{M}\right)$ to the ferrous $\mathrm{Mb}(\mathrm{Mb}(\mathrm{II}))$ solution $\left(5.6 \times 10^{-6} \mathrm{M}\right.$ and $\left.5.6 \times 10^{-5} \mathrm{M}\right)$, in the presence of sodium dithionite $\left(1.0 \times 10^{-2} \mathrm{M}\right)[3]$.

Kinetics and thermodynamics of reductive nitrosylation of cyanide-free and cyanide-bound horse heart $\mathrm{Mb}(\mathrm{III})$ and of cyanide binding to horse heart $\mathrm{Mb}$ (III) were analyzed in the framework of the minimum reaction mechanism represented by Scheme 1 [3-9].

$\mathrm{Mb}(\mathrm{III})$-cyanide $\underset{k_{\mathrm{on}}}{\stackrel{k_{\text {off }}}{\rightleftarrows}} \mathrm{Mb}(\mathrm{III})+$ cyanide

$\mathrm{Mb}(\mathrm{III})+\mathrm{NO} \underset{h_{\text {off }}}{\stackrel{h_{\text {on }}}{\rightleftarrows}} \mathrm{Mb}(\mathrm{III})-\mathrm{NO}$

$\mathrm{Mb}(\mathrm{III})-\mathrm{NO} \stackrel{\text { fast }}{\rightleftarrows} \mathrm{Mb}(\mathrm{II})-\mathrm{NO}^{+}$

$\mathrm{Mb}(\mathrm{II})-\mathrm{NO}^{+}+\mathrm{OH}^{-} \stackrel{\stackrel{l}{\rightarrow}}{\mathrm{Mb}(\mathrm{II})}+\mathrm{HNO}_{2}$

$\mathrm{Mb}(\mathrm{II})+\mathrm{NO} \stackrel{b_{\mathrm{on}}}{\rightarrow} \mathrm{Mb}(\mathrm{II})-\mathrm{NO}$

In the absence of cyanide, values of the (pseudo-)first-order rate constants $h$ and $l$ for horse heart $\mathrm{Mb}$ (III) reductive nitrosylation (i.e., for $\mathrm{NO}$ binding to $\mathrm{Mb}(\mathrm{III})$ and for the $\mathrm{OH}^{-}$-mediated conversion of $\mathrm{Mb}(\mathrm{II})-\mathrm{NO}^{+}$to $\mathrm{Mb}(\mathrm{II})$; reactions $b$ and $d$ in Scheme 1 , respectively) were determined by mixing the $\mathrm{Mb}$ (III) (final concentration, $2.8 \times 10^{-6} \mathrm{M}$ and $2.8 \times 10^{-5} \mathrm{M}$ ) solution with the NO (final concentration, $1.0 \times 10^{-4} \mathrm{M}-1.0 \times 10^{-3} \mathrm{M}$ ) solution under anaerobic conditions, at pH 9.2 (2.0\% borate buffer) and $20.0^{\circ} \mathrm{C}$; no gaseous phase was present [4-9].

Values of $h$ and $l$ were obtained according to Eqs. (1)-(3) [4-10]:

$[\mathrm{Mb}(\mathrm{III})]_{t}=[\mathrm{Mb}(\mathrm{III})]_{i} \times e^{-h \times t}$

$[\mathrm{Mb}(\mathrm{III})-\mathrm{NO}]_{t}=[\mathrm{Mb}(\mathrm{III})]_{i} \times\left(h \times\left(\left(e^{-h \times t} /(l-h)\right)\right.\right.$

$$
\left.\left.+\left(e^{-l \times t} /(h-l)\right)\right)\right)
$$

$[\mathrm{Mb}(\mathrm{II})-\mathrm{NO}]_{t}=[\mathrm{Mb}(\mathrm{III})]_{i}-[\mathrm{Mb}(\mathrm{III})]_{t}+[\mathrm{Mb}(\mathrm{III})-\mathrm{NO}]_{t}$

Values of $h_{\text {on }}$ and $h_{\text {off }}$ (reaction $a$ in Scheme 1) were determined from the dependence of $h$ on the NO concentration (i.e., [NO]), according to Eq. (4) [3]:

$h=h_{\mathrm{on}} \times[\mathrm{NO}]+h_{\mathrm{off}}$

The value of the equilibrium dissociation constant $H$ for horse heart $\mathrm{Mb}(\mathrm{III})$ reductive nitrosylation (i.e., for $\mathrm{NO}$ binding to $\mathrm{Mb}(\mathrm{III})$ ) was determined from the dependence of the molar fraction $\alpha$ of NO-bound $\mathrm{Mb}$ (III) on the free NO concentration (i.e., [NO]), according to Eq. (5) [3]:

$\alpha=[\mathrm{NO}] /([\mathrm{NO}]+H)$

In the presence of cyanide, values of the first-order rate constant $k_{\text {off }}$ for reductive nitrosylation of horse heart $\mathrm{Mb}$ (III) (i.e., for cyanide dissociation from $\mathrm{Mb}(\mathrm{III})$-cyanide complexes) were determined by mixing the $\mathrm{Mb}(\mathrm{III})$-cyanide (final concentration, $2.8 \times 10^{-6} \mathrm{M}$ and $2.8 \times 10^{-5} \mathrm{M}$ ) solution with the NO (final concentration, $\left.1.0 \times 10^{-4} \mathrm{M}-1.0 \times 10^{-3} \mathrm{M}\right)$ solution under anaerobic conditions, at $\mathrm{pH} 9.2$ (2.0\% borate buffer) and $20.0^{\circ} \mathrm{C}$; no gaseous phase was present.

The $k_{\text {off }}$ value was determined from data analysis, according to Eq. (6) [3]:

$[\mathrm{Mb}(\mathrm{III}) \text {-cyanide }]_{t}=[\mathrm{Mb}(\mathrm{III}) \text {-cyanide }]_{i} \times e^{-k_{\text {off }} \times t}$

Values of the pseudo-first-order rate constant $k$ for cyanide binding to horse heart $\mathrm{Mb}(\mathrm{III})$ were obtained by mixing the $\mathrm{Mb}(\mathrm{III})$ (final concentration, $2.8 \times 10^{-6} \mathrm{M}$ and $2.8 \times 10^{-5} \mathrm{M}$ ) solution with the cyanide (final concentration, $5.0 \times 10^{-4} \mathrm{M}-1.0 \times 10^{-2} \mathrm{M}$ ) solution, at pH 9.2 (2.0\% borate buffer) and $20.0^{\circ} \mathrm{C}$ [3].

Values of $k$ were determined from data analysis, according to Eq. (7) [3]:

$[\mathrm{Mb}(\mathrm{III})]_{t}=[\mathrm{Mb}(\mathrm{III})]_{i} \times e^{-k \times t}$

Values of the second-order rate constant $k_{\text {on }}$ for cyanide binding to horse heart $\mathrm{Mb}(\mathrm{III})$ were determined from the dependence of $k$ on the cyanide concentration (i.e., [cyanide]), according to Eq. (8) [3]:

$k=k_{\mathrm{on}} \times[$ cyanide $]$

Kinetics was monitored spectrophotometrically between $380 \mathrm{~nm}$ and $460 \mathrm{~nm}$ and between $500 \mathrm{~nm}$ and $700 \mathrm{~nm}$.

The value of the dissociation equilibrium constant $K$ for cyanide binding to horse heart $\mathrm{Mb}$ (III) was obtained by mixing the $\mathrm{Mb}$ (III) solution (final concentration, $2.8 \times 10^{-6} \mathrm{M}$ ) with the cyanide solution (final concentration, $5.0 \times 10^{-7} \mathrm{M}-1.0 \times 10^{-5} \mathrm{M}$ ), at $\mathrm{pH} 9.2$ (2.0\% borate buffer) and $20.0^{\circ} \mathrm{C}$ [3]. The equilibration time was $24 \mathrm{~h}$.

The value of $K$ was determined from the dependence of the molar fraction $Y$ of cyanide-bound $\mathrm{Mb}$ (III) on the free cyanide concentration (i.e., [cyanide]), according to Eq. (9) [3]:

$Y=[$ cyanide $] /([$ cyanide $]+K)$

Thermodynamics was monitored spectrophotometrically between $380 \mathrm{~nm}$ and $460 \mathrm{~nm}$.

Values of the pseudo-first-order rate constant $b$ for NO binding to horse heart $\mathrm{Mb}$ (II) were obtained by mixing the $\mathrm{Mb}$ (II) (final concentration, $1.4 \times 10^{-6} \mathrm{M}$ ) solution with the NO (final concentration, $\left.6.0 \times 10^{-6} \mathrm{M}-2.0 \times 10^{-5} \mathrm{M}\right)$ solution, at $\mathrm{pH} 9.2(2.0 \%$ borate buffer) and $20.0^{\circ} \mathrm{C}$ [11].

Values of $b$ were determined from data analysis, according to Eq. (10) [11]:

$[\mathrm{Mb}(\mathrm{II})]_{t}=[\mathrm{Mb}(\mathrm{II})]_{i} \times e^{-b \times t}$ 
Values of the second-order rate constant $b_{\text {on }}$ for NO binding to horse heart $\mathrm{Mb}(\mathrm{II})$ were determined from the dependence of $b$ on the NO concentration (i.e., [NO]), according to Eq. (11) [3]:

$b=b_{\text {on }} \times[\mathrm{NO}]$

Kinetics was monitored spectrophotometrically between $380 \mathrm{~nm}$ and $460 \mathrm{~nm}$.

The results are given as mean values of at least four experiments plus or minus the corresponding standard deviation. All data were analyzed using the Matlab program (The Math Works Inc., Natick, MA, USA).

\section{Results and discussion}

Mixing of the horse heart $\mathrm{Mb}$ (III) and NO solutions brings about a shift of the maximum of the absorption peaks from $411 \mathrm{~nm}$ $\left(\varepsilon=119 \mathrm{mM}^{-1} \mathrm{~cm}^{-1}\right), 539 \mathrm{~nm}\left(\varepsilon=8.7 \mathrm{mM}^{-1} \mathrm{~cm}^{-1}\right)$, and $585 \mathrm{~nm}$ $\left(\varepsilon=7.6 \mathrm{mM}^{-1} \mathrm{~cm}^{-1}\right)$ (i.e., $\left.\mathrm{Mb}(\mathrm{III})\right)$, to $418 \mathrm{~nm}\left(\varepsilon=104 \mathrm{mM}^{-1} \mathrm{~cm}^{-1}\right)$, $535 \mathrm{~nm}\left(\varepsilon=12.8 \mathrm{mM}^{-1} \mathrm{~cm}^{-1}\right)$, and $573 \mathrm{~nm}\left(\varepsilon=11.5 \mathrm{mM}^{-1} \mathrm{~cm}^{-1}\right)$ (i.e., $\mathrm{Mb}(\mathrm{III})-\mathrm{NO}$ ) (Fig. 1 and Table $1 \mathrm{~S}$ ). Then, the $\mathrm{Mb}(\mathrm{III})-\mathrm{NO}$ solution undergoes a shift of the maximum of the absorption peaks from $418 \mathrm{~nm}\left(\varepsilon=104 \mathrm{mM}^{-1} \mathrm{~cm}^{-1}\right), 535 \mathrm{~nm}\left(\varepsilon=12.8 \mathrm{mM}^{-1} \mathrm{~cm}^{-1}\right)$, and $573 \mathrm{~nm}\left(\varepsilon=11.5 \mathrm{mM}^{-1} \mathrm{~cm}^{-1}\right)$ (i.e., $\left.\mathrm{Mb}(\mathrm{III})-\mathrm{NO}\right)$, to $417 \mathrm{~nm}$ $\left(\varepsilon=131 \mathrm{mM}^{-1} \mathrm{~cm}^{-1}\right), 544 \mathrm{~nm}\left(\varepsilon=11.5 \mathrm{mM}^{-1} \mathrm{~cm}^{-1}\right)$, and $575 \mathrm{~nm}$ $\left(\varepsilon=10.6 \mathrm{mM}^{-1} \mathrm{~cm}^{-1}\right)$ (i.e., $\mathrm{Mb}(\mathrm{II})-\mathrm{NO}$ ) (Fig. 1 and Table $1 \mathrm{~S}$ ). $\mathrm{Mb}$ (II) was never detected spectrophotometrically because of its very fast reaction with $\mathrm{NO}\left(b_{\mathrm{on}}=1.6 \times 10^{7} \mathrm{M}^{-1} \mathrm{~s}^{-1}\right)$ (Table 1 and Fig. $1 \mathrm{~S}$ ). Note that cyanide binding to heme-Fe(II)-proteins is negligible in comparison with heme-Fe(II) nitrosylation [2,12].

Over the whole NO concentration range explored, the time course for horse heart $\mathrm{Mb}(\mathrm{III})$ reductive nitrosylation corresponds to a biphasic process (Fig. 1); values of $h$ and $l$ are wavelengthindependent at fixed NO concentration. The first step of kinetics
Table 1

Kinetic and thermodynamic parameters for reductive nitrosylation of horse heart $\mathrm{Mb}(\mathrm{III})$ and $\mathrm{Mb}(\mathrm{III})$-cyanide and for cyanide binding to horse heart $\mathrm{Mb}(\mathrm{III})$, at $\mathrm{pH} 9.2$ and $20.0^{\circ} \mathrm{C}$. .

\begin{tabular}{ll}
\hline Reductive nitrosylation & \\
$\mathrm{Mb}(\mathrm{III})$ & $h_{\text {on }}=6.8 \times 10^{4} \mathrm{M}^{-1} \mathrm{~s}^{-1}$ \\
& $h_{\text {off }}=5.2 \mathrm{~s}^{-1}$ \\
& $H=1.2 \times 10^{-4} \mathrm{M}$ \\
& $H=h_{\text {off }} / h_{\mathrm{on}}=7.6 \times 10^{-5} \mathrm{M}$ \\
& $l=6.2 \times 10^{-3} \mathrm{~s}^{-1}$ \\
& $b_{\text {on }}=1.6 \times 10^{7} \mathrm{M}^{-1} \mathrm{~s}^{-1}$ \\
& $k_{\text {off }}=4.3 \times 10^{-4} \mathrm{~s}^{-1}$ \\
$\mathrm{Mb}(\mathrm{III})$-cyanide & \\
$\mathrm{Cyanide}$ binding & $k_{\text {on }}=3.1 \times 10^{2} \mathrm{M}^{-1} \mathrm{~s}^{-1}$ \\
$\mathrm{Mb}(\mathrm{III})$ & $K=1.3 \times 10^{-6} \mathrm{M}$ \\
& $k_{\text {off }}=k_{\mathrm{on}} \times K=4.4 \times 10^{-4} \mathrm{~s}^{-1}$ \\
\hline
\end{tabular}

${ }^{\text {a }}$ For details, see Scheme 1.

for $\mathrm{Mb}(\mathrm{III})$ reductive nitrosylation (indicated by $h_{\text {on }}$ in Scheme 1 ) is a bimolecular process as observed under pseudo-first order conditions (Fig. 1). The plot of $h$ versus [NO] is linear (Eq. (4)), the slope corresponds to $h_{\text {on }}\left(=6.8 \times 10^{4} \mathrm{M}^{-1} \mathrm{~s}^{-1}\right)$ (Table 1$)$. The $y$ intercept of plots of $h$ versus [NO] corresponds to $h_{\text {off }}\left(=5.2 \mathrm{~s}^{-1}\right)$ (Table 1$)$. In contrast, the second step (indicated by $l$ in Scheme 1) follows a [NO]-independent mono-molecular behavior (Fig. 1); the average value of $l \mathrm{Mb}$ (II) formation is $6.2 \times 10^{-3} \mathrm{~s}^{-1}$ (Table 1 ).

Fig. 1 shows the dependence of the molar fraction of $\mathrm{Mb}(\mathrm{III})-\mathrm{NO}$ (i.e., $\alpha$ ) on the free NO concentration (i.e., [NO]). The analysis of data according to Eq. (5) allowed to determine the value of $H$ for NO binding to $\mathrm{Mb}(\mathrm{III})\left(=1.2 \times 10^{-4} \mathrm{M}\right)$ (Table 1$)$. Consistently with the stoichiometry of reaction $b$ in Scheme 1, the value of the Hill coefficient $n$ is $1.00 \pm 0.02$. As expected for simple systems [3], the value of $H\left(=h_{\text {off }} / h_{\text {on }}\right)$ determined experimentally (= $1.2 \times 10^{-4} \mathrm{M}$ ) is in agreement with that of the $h_{\text {off }} / h_{\text {on }}$ ratio (= $\left.7.6 \times 10^{-5} \mathrm{M}\right)($ Table 1$)$.
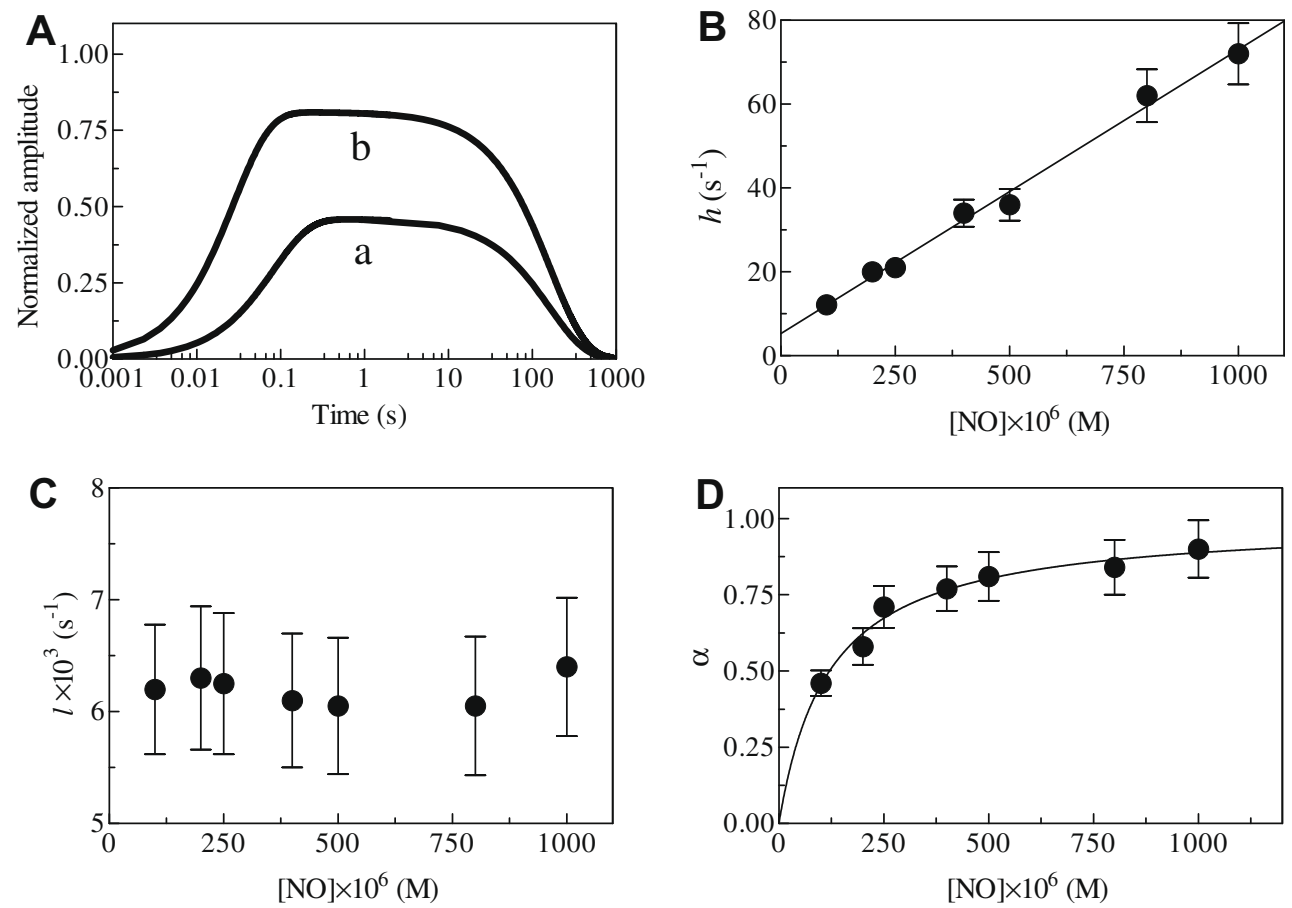

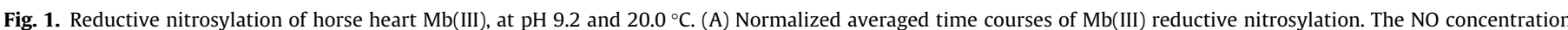

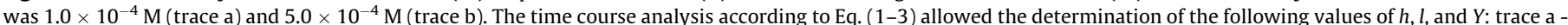

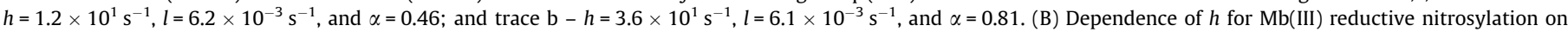

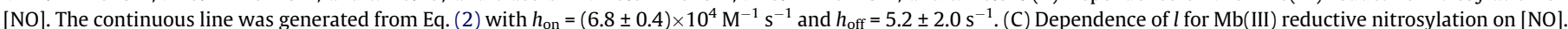

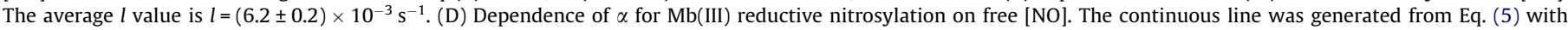
$H=(1.2 \pm 0.3) \times 10^{-4} \mathrm{M}$. The $\mathrm{Mb}(\mathrm{III})$ concentration was $2.8 \times 10^{-6} \mathrm{M}$ and $2.8 \times 10^{-5} \mathrm{M}$. For details, see text. 
Mixing of horse heart $\mathrm{Mb}(\mathrm{III})$-cyanide and NO solutions induces a shift of the maximum of the absorption peaks from $422 \mathrm{~nm}$ $\left(\varepsilon=116 \mathrm{mM}^{-1} \mathrm{~cm}^{-1}\right)$ and $541 \mathrm{~nm}\left(\varepsilon=11.2 \mathrm{mM}^{-1} \mathrm{~cm}^{-1}\right) \quad$ (i.e., $\mathrm{Mb}(\mathrm{III})$-cyanide $)$ to $417 \mathrm{~nm} \quad\left(\varepsilon=131 \mathrm{mM}^{-1} \mathrm{~cm}^{-1}\right), \quad 544 \mathrm{~nm}$ $\left(\varepsilon=11.5 \mathrm{mM}^{-1} \mathrm{~cm}^{-1}\right)$, and $575 \mathrm{~nm}\left(\varepsilon=10.6 \mathrm{mM}^{-1} \mathrm{~cm}^{-1}\right)$ (i.e., $\mathrm{Mb}(\mathrm{II})-\mathrm{NO})$ (Fig. 2 and Table $1 \mathrm{~S}$ ).

Over the whole NO concentration range explored, the time course of $\mathrm{Mb}$ (III)-cyanide reductive nitrosylation corresponds to a mono-exponential process for more than $95 \%$ of its course (Fig. 2). The value of the first-order rate constant for reductive nitrosylation of $\mathrm{Mb}(\mathrm{III})$-cyanide is wavelength- and [NO]-independent (Fig. 2), the average value being $4.3 \times 10^{-4} \mathrm{~s}^{-1}$ (Table 1 ).

Remarkably, ( $i$ ) the $\mathrm{Mb}$ (III), $\mathrm{Mb}$ (III)-NO, and $\mathrm{Mb}$ (II) species were never detected spectrophotometrically, (ii) the value of the first-order rate constant for reductive nitrosylation of $\mathrm{Mb}$ (III)-cyanide (= $4.3 \times 10^{-4} \mathrm{~s}^{-1}$ ) is lower than those of kinetic parameters for reductive nitrosylation of $\mathrm{Mb}(\mathrm{III})$ by several orders of magnitude (Table 1), and (iii) the value of the first-order rate constant for reductive nitrosylation of $\mathrm{Mb}(\mathrm{III})$-cyanide is reminiscent to those reported in the literature for cyanide dissociation from heme$\mathrm{Fe}(\mathrm{III})$-cyanide complexes $[1,2]$. These data suggest that cyanide dissociation from horse heart $\mathrm{Mb}(\mathrm{III})$-cyanide represents the rate-limiting step of reductive nitrosylation, as described in Scheme 1. Therefore, the first-order rate constant for reductive nitrosylation of $\mathrm{Mb}(\mathrm{III})$-cyanide corresponds to the first-order rate constant for cyanide dissociation, i.e., $k_{\text {off }}$ (reaction $a$ in Scheme 1 ).

Mixing of the horse heart $\mathrm{Mb}(\mathrm{III})$ and cyanide solutions brings about a shift of the maximum of the absorption peaks from
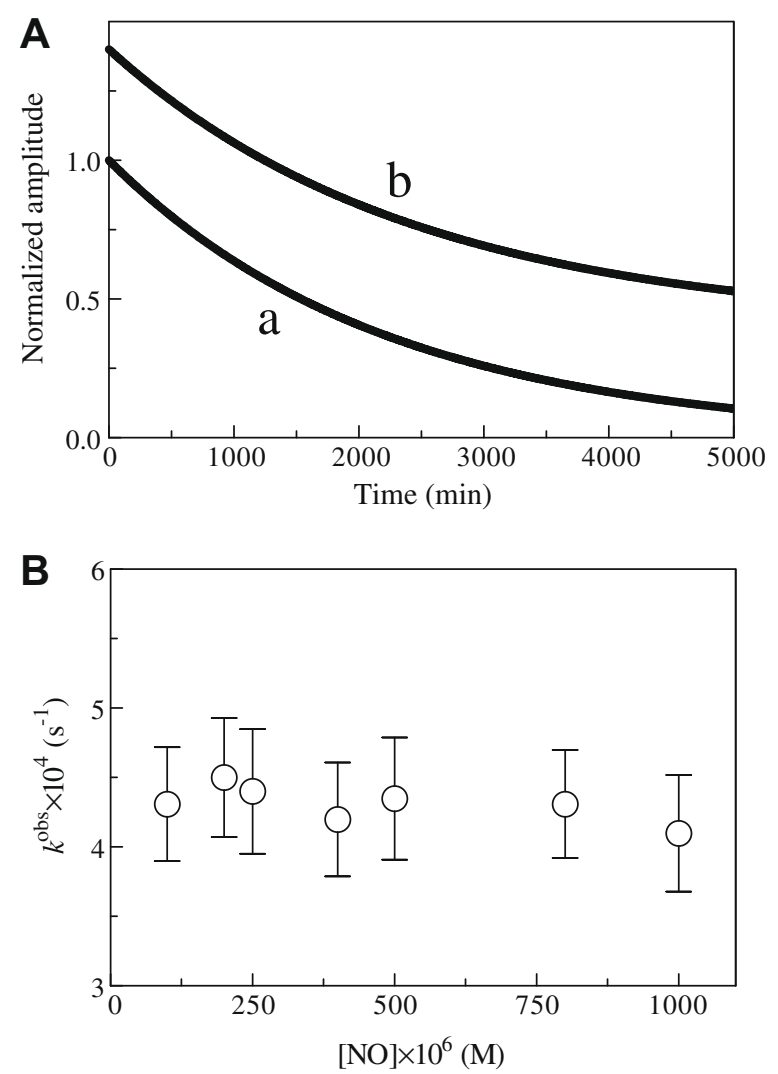

Fig. 2. Reductive nitrosylation of cyanide-bound horse heart $\mathrm{Mb}(\mathrm{III})$, at $\mathrm{pH} 9.2$ and $20.0^{\circ} \mathrm{C}$. (A) Normalized averaged time courses for reductive nitrosylation of $\mathrm{Mb}$ (III)-cyanide. The NO concentration was $2.0 \times 10^{-4} \mathrm{M}$ (trace a) and $1.0 \times 10^{-3} \mathrm{M}$ (trace b). The time course analysis according to Eq. (6) allowed the determination of the following values of $k_{\text {off }}=4.5 \times 10^{-4} \mathrm{~s}^{-1}$ (trace a) and $4.1 \times 10^{-4} \mathrm{~s}^{-1}$ (trace b). (B) Dependence of $k_{\mathrm{off}}$ for reductive nitrosylation of $\mathrm{Mb}(\mathrm{III})$-cyanide on [NO]. The average $k_{\text {off }}$ value is $4.3 \times 10^{-4} \mathrm{~s}^{-1}$. The $\mathrm{Mb}(\mathrm{III})$ concentration was $2.8 \times 10^{-6} \mathrm{M}$ and $2.8 \times 10^{-5} \mathrm{M}$. For details, see text.
$411 \mathrm{~nm}\left(\varepsilon=119 \mathrm{mM}^{-1} \mathrm{~cm}^{-1}\right), 539 \mathrm{~nm}\left(\varepsilon=8.7 \mathrm{mM}^{-1} \mathrm{~cm}^{-1}\right)$, and $585 \mathrm{~nm}\left(\varepsilon=7.6 \mathrm{mM}^{-1} \mathrm{~cm}^{-1}\right) \quad$ (i.e., $\left.\mathrm{Mb}(\mathrm{III})\right)$ to $422 \mathrm{~nm}$ $\left(\varepsilon=116 \mathrm{mM}^{-1} \mathrm{~cm}^{-1}\right)$ and $541 \mathrm{~nm}\left(11.2 \mathrm{mM}^{-1} \mathrm{~cm}^{-1}\right)$ (i.e., $\mathrm{Mb}(\mathrm{III})-$ cyanide) (Table $1 \mathrm{~S}$ ).

The time course of cyanide binding to horse heart $\mathrm{Mb}$ (III) corresponds to a mono-exponential process for more than $95 \%$ of its course. Values of the pseudo-first-order rate constant for $\mathrm{Mb}$ (III)cyanide formation (i.e., $k$ ) are wavelength-independent at fixed cyanide concentration. The plot of $k$ versus [cyanide] is linear (Eq. (8)), the slope of the plot corresponds to $k_{\text {on }}$ (Fig. 3 ). The value of $k_{\text {on }}$ for cyanide binding to horse heart $\mathrm{Mb}(\mathrm{III}) \quad(=$ $3.4 \times 10^{2} \mathrm{M}^{-1} \mathrm{~s}^{-1}$ ) (Table 1 ) is closely similar to that reported in the literature $\left(=3.1 \times 10^{2} \mathrm{M}^{-1} \mathrm{~s}^{-1}\right.$, at $\mathrm{pH} 9.1$ and $\left.21-23^{\circ} \mathrm{C}\right)$ [3].

Fig. 3 shows the dependence of the molar fraction of $\mathrm{Mb}(\mathrm{III})-$ cyanide (i.e., $Y$ ) on the free cyanide concentration (i.e., [cyanide]). The analysis of data according to Eq. (9) allowed to determine the value of $K$ for cyanide binding to $\mathrm{Mb}(\mathrm{III})\left(=1.3 \times 10^{-6} \mathrm{M}\right)(\mathrm{Ta}-$ ble 1$)$. Consistently with the stoichiometry of reaction $a$ in Scheme 1 , the value of the Hill coefficient $n$ is $1.01 \pm 0.02$. The value of $K$ here determined (Table 1 ) agrees with that reported in the literature $\left(=4.4 \times 10^{-6} \mathrm{M}\right.$, at $\mathrm{pH} 9.1$ and $\left.21-23^{\circ} \mathrm{C}\right)$ [3].

A very important point to underline is that this represents the first direct measurement of the cyanide dissociation kinetics from horse heart $\mathrm{Mb}(\mathrm{III})$-cyanide, which exploits the fact that the reductive nitrosylation of horse heart $\mathrm{Mb}$ (III)-cyanide occurs with a reaction mechanism in which cyanide dissociation represents the rate-limiting step. Therefore, heme-Fe(III) reduction by NO takes place with unliganded $\mathrm{Mb}(\mathrm{III})$ only after the cyanide dissociation.
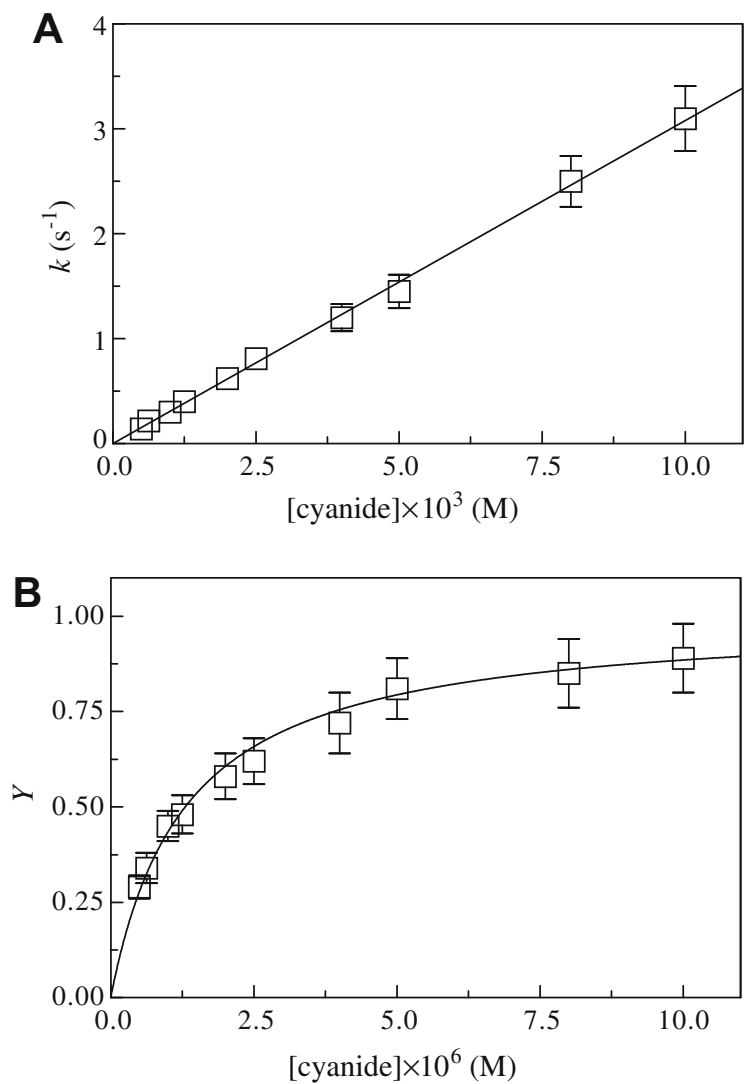

Fig. 3. Kinetics and thermodynamics of cyanide binding to horse heart $\mathrm{Mb}(\mathrm{III})$, at $\mathrm{pH} 9.2$ and $20.0^{\circ} \mathrm{C}$. (A) Dependence of $k$ for cyanide binding to $\mathrm{Mb}$ (III) on [cyanide]. The continuous line was generated from Eq. (8) with $k_{\text {on }}=(3.1 \pm 0.3) \times 10^{2} \mathrm{M}^{-1} \mathrm{~s}^{-1}$ The $\mathrm{Mb}(\mathrm{III})$ concentration was $2.8 \times 10^{-6} \mathrm{M}$. (B) Dependence of $Y$ for cyanide binding to $\mathrm{Mb}$ (III) on the free ligand concentration (i.e., [cyanide]). The continuous line was generated from Eq. (9) with $K=(1.3 \pm 0.2) \times 10^{-6} \mathrm{M}$. The $\mathrm{Mb}$ (III) concentration was $1.4 \times 10^{-6} \mathrm{M}$. For details, see text. 
To our knowledge, the use of NO is the only way to observe directly the cyanide dissociation process from $\mathrm{Mb}(\mathrm{III})$-cyanide, since for this observation to be correct we need that the cyanide dissociation process is the only rate-limiting step. Therefore, a caution must be applied in checking that, indeed this is true under the experimental conditions employed.

As a matter of fact, the measurements reported in this work have been carried at $\mathrm{pH}>9.0$, because at lower $\mathrm{pH}$ values the step $(d)$ of Scheme 1 becomes slow enough to affect the observed measurements $[4,5]$. On the other hand, caution must be also paid on that the observed cyanide dissociation process occurs for the $\mathrm{Mb}(\mathrm{III})-$ cyanide complex. In this respect, this mechanism is completely different from that occurring upon $\mathrm{Mb}$ (III)-cyanide reduction by sodium dithionite, which involves instead the transient formation of the heme-Fe(II)-cyanide species, which then decays to heme-Fe(II) due to its very low affinity for cyanide $[1,2,13]$. Thus, in this last case only cyanide dissociation from $\mathrm{Mb}(\mathrm{II})$-cyanide can be investigated. As a whole, data here reported represent the first quantitative analysis of reductive nitrosylation (i.e., NO-mediated reduction) of the cyanide derivative of a heme-Fe(III)-protein which appears to be limited by cyanide dissociation kinetics. This study opens the possibility to determine quantitatively cyanide dissociation kinetics from heme-Fe(III)-proteins. The correctness of the approach presented in this work is strengthened by the fact that the $k_{\text {off }}$ value obtained experimentally $\left(=4.3 \times 10^{-4} \mathrm{~s}^{-1}\right)$ matches well to that calculated from values of $k_{\text {on }}$ and $K$ for cyanide binding to horse heart $\mathrm{Mb}(\mathrm{III})\left(k_{\mathrm{off}}=k_{\mathrm{on}} \times K=4.4 \times 10^{-4} \mathrm{~s}^{-1}\right)$ (Table 1$)$.

In conclusion, the different mechanisms describing NO- and dithionite-induced reduction of horse heart $\mathrm{Mb}(\mathrm{III})$-cyanide (see present study and [1,2]) are important since reduction of $\mathrm{Mb}$ (III)-cyanide may be used to determine the first-order rate constant of cyanide dissociation (i.e., $k_{\text {off }}$ ). However, some caution is demanded since cyanide dissociation must be slower than heme$\mathrm{Fe}(\mathrm{III})$-atom reduction, as reported here for reductive nitrosylation of $\mathrm{Mb}(\mathrm{III})$-cyanide.

\section{Acknowledgements}

This work was partially supported by grants from the Ministry for University and Research of Italy (University 'Roma Tre', Roma,
Italy, 'CLAR 2009' to P.A. and University of Roma 'Tor Vergata', Roma, Italy, '60\%' to M.C.).

\section{Appendix A. Supplementary data}

Supplementary data associated with this article can be found, in the online version, at doi:10.1016/j.bbrc.2010.01.092.

\section{References}

[1] M. Milani, Y. Ouellet, H. Ouellet, M. Guertin, A. Boffi, G. Antonini, A. Bocedi, M. Mattu, M. Bolognesi, P. Ascenzi, Cyanide binding to truncated hemoglobins: a crystallographic and kinetic study, Biochemistry 43 (2004) 5213-5221.

[2] A. Bolli, C. Ciaccio, M. Coletta, M. Nardini, M. Bolognesi, A. Pesce, M. Guertin, P. Visca, P. Ascenzi, Ferrous Campylobacter jejuni truncated hemoglobin P displays an extremely high reactivity for cyanide: a comparative study, FEBS J. 275 (2008) 633-645.

[3] E. Antonini, M. Brunori, Hemoglobin and Myoglobin in their Reactions with Ligands, North-Holland Publishing Co., Amsterdam, 1971.

[4] M. Hoshino, K. Ozawa, H. Seki, P.C. Ford, Photochemistry of nitric oxide adducts of water-soluble iron(III) porphyrin and ferrihemoproteins studied by nanosecond laser photolysis, J. Am. Chem. Soc. 115 (1993) 9568-9575.

[5] M. Hoshino, M. Maeda, R. Konishi, H. Seki, P.C. Ford, Studies on the reaction mechanism for reductive nitrosylation of ferrihemoproteins in buffer solutions, J. Am. Chem. Soc. 118 (1996) 5702-5707.

[6] A. Boffi, P. Sarti, G. Amiconi, E. Chiancone, The interplay between heme iron and protein sulfhydryls in the reaction of dimeric Scapharca inaequivalvis hemoglobin with nitric oxide, Biophys. Chem. 98 (2002) 209-216.

[7] S. Herold, A. Fago, R.E. Weber, S. Dewilde, L. Moens, Reactivity studies of the $\mathrm{Fe}(\mathrm{III})$ and $\mathrm{Fe}(\mathrm{II}) \mathrm{NO}$ forms of human neuroglobin reveal a potential role against oxidative stress, J. Biol. Chem. 279 (2004) 22841-22847.

[8] S. Herold, A. Puppo, Kinetics and mechanistic studies of the reactions of metleghemoglobin, ferrylleghemoglobin, and nitrosylleghemoglobin with reactive nitrogen species, J. Biol. Inorg. Chem. 10 (2005) 946-957.

[9] P. Ascenzi, A. Bocedi, G. Antonini, M. Bolognesi, M. Fasano, Reductive nitrosylation and peroxynitrite-mediated oxidation of heme-hemopexin, FEBS J. 274 (2007) 551-562.

[10] H. Bateman, Solution of a system of differential equations occurring in the theory of radio-active transformations, Proc. Cambridge Phyl. Soc. 15 (1910) 423-427.

[11] R. Cassoly, Q.H. Gibson, Conformation, co-operativity and ligand binding in human hemoglobin, J. Mol. Biol. 91 (1975) 301-313.

[12] M. Brunori, M. Coletta, P. Ascenzi, M. Bolognesi, Kinetic control of ligand binding processes in hemoproteins, J. Mol. Liquids 42 (1989) 175-193.

[13] A. Bellelli, G. Antonini, M. Brunori, B.A. Springer, S.G. Sligar, Transient spectroscopy of the reaction of cyanide with ferrous myoglobin. Effect of distal side residues, J. Biol. Chem. 265 (1990) 18898-18901. 